\title{
Optimization of Energy Consumption in the Process of Dehumidification of Natural Gas
}

\author{
Nima Norouzi ${ }^{1(\mathbb{D})}$, Navid Shiva ${ }^{2(\mathbb{D})}$, Hossein Khajehpour ${ }^{3, *(\mathbb{D})}$ \\ 1 Energy and Physics Department, Amirkabir University of Technology, 424 Hafez Ave. Tehran, Iran; nima1376@aut.ac.ir \\ (N.N.); \\ 2 Energy and Physics Department, Amirkabir University of Technology, 424 Hafez Ave. Tehran, Iran; \\ navidshiva1991@gmail.com (N.S.); \\ 3 Energy Department, Sharif University of Technology, Ostad Moein Tehran, Iran, khajehpour@energy.sharif.edu (H.K.); \\ * Correspondence: hkhajehpour2020@gmail.com;
}

Received:

\begin{abstract}
In recent years, there has been a great tendency to optimize energy consumption in the oil and gas industry's upstream and downstream equipment. One of the most energy-intensive processes in natural gas refineries is the condensate stabilization unit (gas condensate). The main bottlenecks of energy consumption in the old units are condensated stabilization (dehumidification with ethylene glycol), heater reboiler, and air coolers (air coolers). Therefore, much attention should be paid to these applications and electricity and steam consumption in this unit. In this study, a simulated model based on the Gachsaran gas refinery's new layout has been developed. Optimization of this part of the existing process is preheating the inlet flow to the reboiler by adding a two-stage shell-tube heat exchanger. This reduces the amount of steam needed to evaporate the inlet stream to the end of the tower. On the other hand, by pre-cooling the inlet currents to the air conditioners, the amount of electricity consumed to reach the outlet flows' the desired temperature would be reduced. The results show an attractive return on investment for the remediation plan, a reduction in energy demand, and an increase in the unit's productivity.
\end{abstract}

Keywords: gas dehumidification; reboiler; air cooler; thermal integration; distillation tower; liquidliquid adsorption.

\footnotetext{
(C) 2021 by the authors. This article is an open-access article distributed under the Creative Commons Attribution (CC BY) license (https://creativecommons.org/licenses/by/4.0/).
}

\section{Introduction}

Dehumidification is one of the stages of natural gas purification. After separating oil from gas, some free water and natural gas are separated from the gas by simple separation methods at or near the wellhead. Simultaneously, the water vapor in the gas solution must be separated from natural gas in a complex process called desalination or dehumidification operation [1]. In this process, dense water vapor present on the surface is absorbed and collected by the desiccant.

The common type of absorption dehumidifier is known as glycol dehumidification, which is the main ingredient in this process. In this process, a glycol-containing desiccant dehumidifier is used to absorb water vapor from the gas stream. In this type of process, two solutions of glycol, diethyl glycol (DEG) or triethyl glycol (TEG), are often used [2].

The molecular properties of glycol are very similar to water, so if it comes in contact with a stream of natural gas, it absorbs and collects the water's moisture in the gas stream. The 
heavier molecules of the glycol accumulate at the contact end to exit the dehumidifier, then the dry natural gas is transferred to the outside of the dehumidifier [3].

The glycol solution is passed through a boiler to evaporate the dissolved water and release the glycol for reuse in subsequent dehumidification processes. This is done using the physical phenomenon, i.e., the difference in the boiling point of water up to 212 degrees Fahrenheit (100 degrees Celsius) and glycol to 400 degrees Fahrenheit [4].

Ethylene glycol dehumidification units and gas condensate stabilization are some of the most important and, at the same time, the most widely used parts of gas refineries [5]. The presence of water vapor in the gas at low temperatures and high pressures can cause the formation of hydrates, and even the presence of hydrogen sulfide and carbon dioxide can cause corrosion [6]. In these units, a common method is to remove water from the gas by adsorbing it through the tower and contacting it with ethylene glycol, followed by partial distillation of the mixture [7]. In this process, triethylene glycol (TEG) and diethylene glycol (DEG) have been used for this purpose [8].

Dehumidification units generally use an adsorption distillation tower, flash tank, heat exchanger, and regenerator, as shown in Figure 1 [9]. The moisture-rich gas stream enters the three-phase separator, and the gas part is separated and exits from above, and in the next stages, it is mixed with the product flow. The concentrated liquid stream also separates from the bottom and enters the reduction process [10]. Ethylene glycol is injected into the inlet stream and enters the tower from above. After the vapor-free gas adsorption process, it exits the top of the tower to reach the desired condition, and a stream of concentrated glycol exits the bottom of the tower and enters the reboiler to regenerate and return to the inside of the tower [11]. The boiler heat load is supplied by low-pressure steam (LPS) flow [12].

Finally, the dry gas is compressed in the compressor, and its temperature is reduced by an air cooler (100), and it is ready to be transferred to the sweetening unit. Another current flows from the bottom of the tower to the NGL unit for recycling, which first raises the temperature through a pump designed to provide the desired pressure and then reaches the desired temperature through an air cooler (101) [13].

In this paper, a simulated model of the Gachsaran refinery gas dehumidification unit was developed based on operational and real data. Therefore, the intensity of energy consumption in this unit's equipment-consuming energy is presented in Table 1 below. This model is also used to measure energy management after implementing the new arrangement [14].

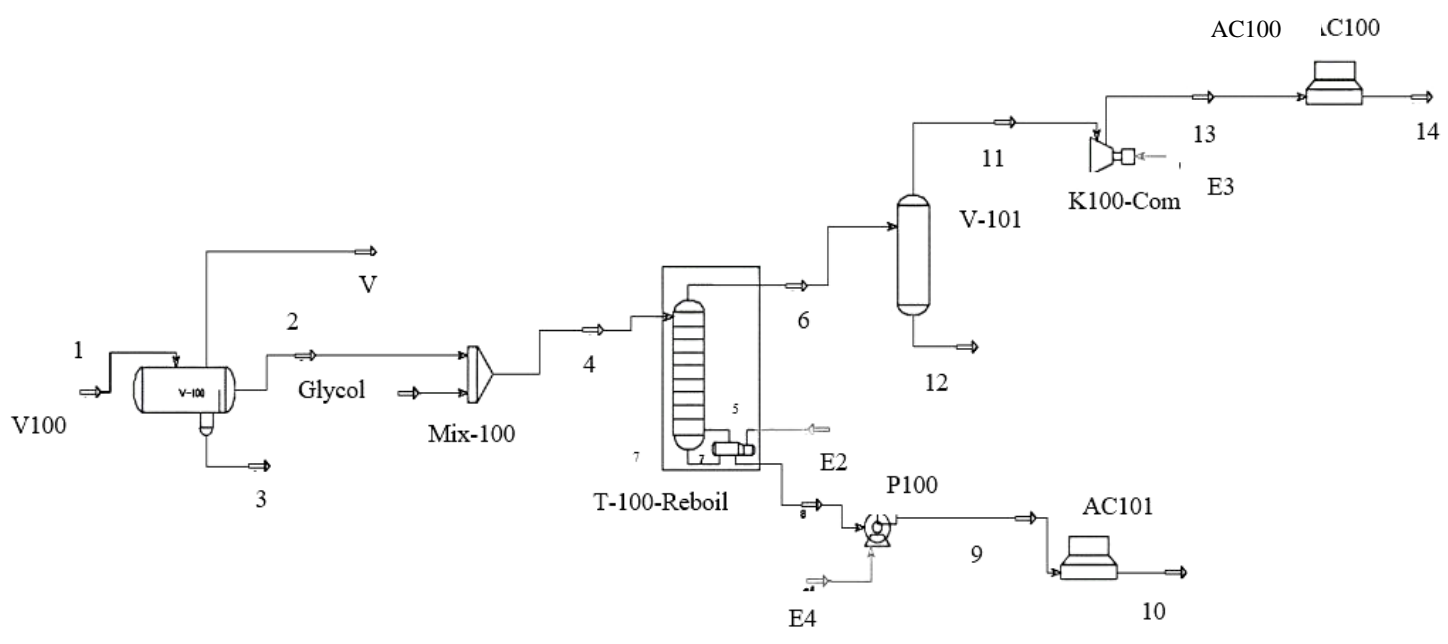

Figure 1. A general overview of the natural gas dehumidification process. 
Table 1. The intensity of energy consumption in the main equipment.

\begin{tabular}{c|c} 
Equipment & $\mathbf{k W h} / \mathbf{t} \mathbf{N G}$ \\
\hline Reboiler & 71.581 \\
\hline Compressor & 20.423 \\
\hline Pump & 2.041 \\
\hline Air converter & 43.43
\end{tabular}

\section{Materials and Methods}

Modification model based on available data on equipment performance developed in Hysys V.7 software and simulated with customization technique in that software to obtain outputs similar to real and operational data. In this study, the thermodynamic model based on Peng-Robinson equations is used. On the other hand, heat exchangers are designed with Aspen Heat Exchanger Design V.7 software and are connected to simulation software. Besides equipment specifications based on the available designs, the operating conditions have also been optimized so that each piece of equipment works at its optimal point [15-20].

\section{Results and Discussion}

\subsection{Optimal configuration.}

A new configuration has been introduced in this paper as a retrofit and optimization strategy [21]. This new configuration, as shown in Figure 2, focuses on heat recovery from the dry natural gas outflow from the compressor to reduce the heat load from the boiler (reboiler) as well as to reduce the electrical demand of the axial fans from the air heat exchanger (air cooler) [22]. For this purpose, two shell and tube heat exchangers (E100 and E101) have been added to this unit.

According to this configuration, the compressed gas (13) heat will be transferred from the compressor at 39.8 bar and $143.5^{\circ} \mathrm{C}$ to the downstream flow of the stripper column. Therefore, its temperature also drops to 80 degrees Celsius. At the output point of the heat exchanger (E100), the downstream discharger (17) is biphasic (liquid/steam). It then flows to the heat exchanger shell of the second stage (E101), which increases the temperature to about $85^{\circ} \mathrm{C}$ by transferring heat from the pump's outlet (9) [23]. Finally, the output current from the second heat exchanger (18) flows to the reboiler with the same process conditions as the initial state, and as a result, the steam consumption of the reboiler decreases due to the increase of its inlet flow temperature [24].

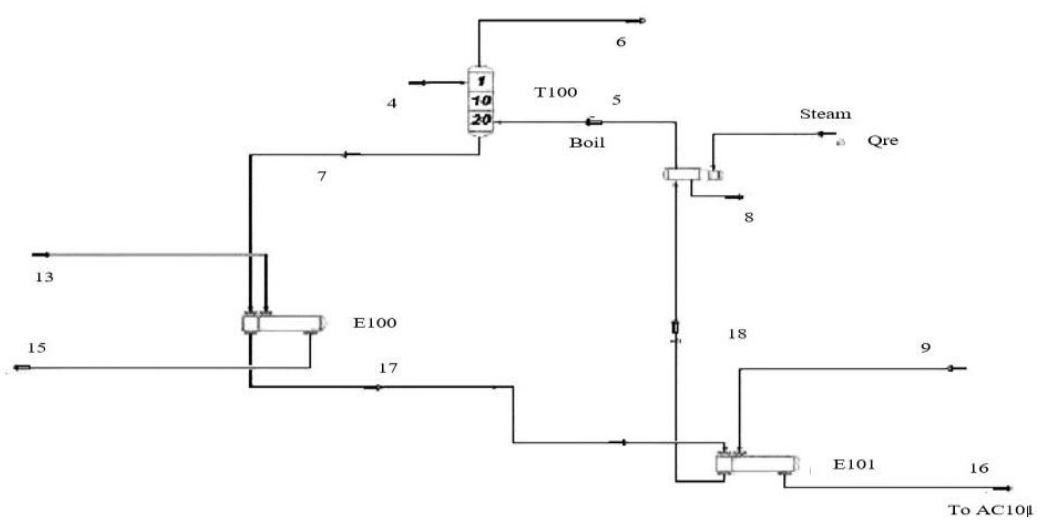

Figure 2. An example view of a new configuration in the gas moisture absorption process. 
Due to the heat transfer process in E100 and E101, the compressor and pump's outlet temperature is reduced. As a result, the inlet currents of air coolers are reduced and the electrical load consumed by their motors (set to cool these currents). The physical conditions of all currents in the new arrangement are shown in Table 2 [25-27]:

Table 2. Physical conditions of streams in the new arrangement.

\begin{tabular}{l|c|c|r|r|r|r} 
State & \multicolumn{1}{c|}{$\mathbf{4}$} & \multicolumn{1}{c|}{$\mathbf{6}$} & \multicolumn{1}{c|}{$\mathbf{8}$} & \multicolumn{1}{c|}{$\mathbf{1 3}$} & \multicolumn{1}{c}{$\mathbf{9}$} & \multicolumn{1}{c}{$\mathbf{7}$} \\
\hline Steam component & 25.0 & 0.1 & 0.0 & 0.1 & 0.0 & 0.0 \\
\hline Temperature $[\mathrm{C}]$ & 18.1 & 27.73 & 97 & 143.48 & 99.93 & 75.76 \\
\hline Pressure $[\mathrm{kPa}]$ & 1090 & 1020 & 1066 & 3980 & 4090 & 1025.43 \\
\hline Mass flow $[\mathrm{kg} / \mathrm{h}]$ & 16343.34 & 4334.05 & 11996.43 & 4334.05 & 11979.43 & 19519.51 \\
\hline State & 17 & 18 & 5 & 15 & 16 & \multicolumn{1}{c}{ vapor } \\
\hline Steam component & 0.043 & 0.137 & 0.1 & 1.0 & 0.0 & 1.0 \\
\hline Temperature $[\mathrm{C}]$ & 81.08 & 84.80 & 97 & 82 & 85 & 151.84 \\
\hline Pressure $[\mathrm{kPa}]$ & 1098 & 1096 & 1066 & 3960 & 3959 & 500 \\
\hline Mass flow $[\mathrm{kg} / \mathrm{h}]$ & 19519.24 & 19519.24 & 7522.60 & 4334.04 & 11979.30 & 983.40
\end{tabular}

\subsection{Results.}

The comparison between the existing system and new modifications in the dehumidification unit of the Gachsaran gas refinery is shown in Table 3. The results show that the new arrangement's application can reduce the unit demand level from $137.5 \mathrm{kWh}$ per ton of liquefied natural gas to $92.2 \mathrm{kWh} / \mathrm{t}_{\mathrm{NG}}$. This saving is achieved by reducing the electric charge of air coolers by $53.71 \%$ and reducing the thermal load (and the need for low-pressure steam) in the reboiler to $40.45 \%$.

Table 3. Comparison between the existing system and the new design in the unit.

\begin{tabular}{l|c|c} 
& Available makeup & New makeup \\
\hline Dry gas production $(\mathrm{t} / \mathrm{h})$ & 17.12 & 19.41 \\
\hline Rebuiler heat load $(\mathrm{kWh})$ & 883.6 & 526.2 \\
\hline Energy consumed by Air conditioner Heat exchangers $(\mathrm{kWh})$ & 98.27 & 95.12
\end{tabular}

The initial capital cost required for these process modifications in the unit mentioned in Table 4 is presented. These feasibility results show that this project's economic return is very attractive, and there are also opportunities to improve the unit's efficiency. If the unit price of electricity is considered to be $\$ 0.04$ per kilowatt-hour and the cost of steam production is estimated at $\$ 6.5$ per ton, and taking into account the total capital costs including the two heat exchangers added, the internal rate of return This project is estimated at $46 \%$.

Table 4. Capital costs for new makeup.

\begin{tabular}{l|c|c} 
Equipment & Size $\left(\mathbf{m}^{\mathbf{2}}\right)$ & Capital cost $\mathbf{( \$ \mathbf { ~ 1 0 } ^ { \mathbf { 3 } } )}$ \\
\hline Heat exchanger E100 & 7.5 & 9.8 \\
\hline Heat exchanger E101 & 40 & 16 \\
\hline whole & 47.5 & 25.8
\end{tabular}

\section{Conclusions}

The purpose of this study was to work on a new design of the gas condensate stabilization unit process to achieve thermal recovery from high energy flows to the energy seeker in the process. In the new configuration with energy integration, $53.71 \%$ of electrical energy and $40.45 \%$ of thermal energy are obtained. We would also have the least impact on unit equipment by using a method to reduce capital and operating costs. For this purpose, the total initial cost, which is about $\$ 25.8$ thousand, with the net present value (NPV) of the project 
during the 15 years of operation of the system, estimated at $\$ 108.491$, will support the economic feasibility of the project.

\section{Funding}

This research received no external funding.

\section{Acknowledgments}

The authors acknowledge the scientific support of the Iranian Ministry of Petroleum's deputy and the Gachsaran gas refinery plant's management.

\section{Conflicts of Interest}

The authors declare no conflict of interest.

\section{References}

1. Norouzi, N.; Talebi, S. An overview on the green petroleum production. Chemical Review and Letters 2020, 4, 9-15, https://dx.doi.org/10.22034/crl.2020.222515.1041.

2. Norouzi, N.; Fani, M.; Ziarani, Z.K. The fall of oil Age:A scenario planning approach over the last peak oil of human history by 2040. Journal of Petroleum Science and Engineering 2020, 188, 106827, https://doi.org/10.1016/j.petrol.2019.106827.

3. Mirvakili, A.; Chahibakhsh, S.; Ebrahimzadehsarvestani, M.; Soroush, E.; Rahimpour, M.R. Modeling and assessment of novel configurations to enhance methanol production in industrial mega-methanol synthesis plant. Journal of the Taiwan Institute of Chemical Engineers 2019, 104, 40-53, https://doi.org/10.1016/j.jtice.2019.09.018.

4. Chen, K.; Yu, J.; Liu, B.; Si, C.; Ban, H.; Cai, W.; Li, C.; Li, Z.; Fujimoto, K. Simple strategy synthesizing stable $\mathrm{CuZnO} / \mathrm{SiO} 2$ methanol synthesis catalyst. J. Catal. 2019, 372, 163-173, https://doi.org/10.1016/j.jcat.2019.02.035.

5. Norouzi, N.; Talebi, S. Exergy and Energy Analysis of Effective Utilization of Carbon Dioxide in the Gasto-Methanol Process. Iranian Journal of Hydrogen \& Fuel Cell 2020, 7, 13-31, https://doi.org/10.22104/ijhfc.2020.4134.1203.

6. Norouzi, N.; Talebi, S.; Shahbazi, A.; An overview on the carbon capture technologies with an approach of green coal production study. Chemical Review and Letters, 2020; 3(2): 65-78, https://doi.org/10.22034/crl.2020.224177.1043.

7. Norouzi, N.; Talebi, S.; Shahbazi, A. An overview on the carbon capture technologies with an approach of green coal production study. Chemical Review and Letters 2020, 3, 65-78, https://doi.org/10.33263/Materials22.219230

8. Fani, M.; Norouzi, N. Numerical Modeling of Thermal Energy Storage of CHPs in Porous Concrete. Mat Int 2020, 2, 0191-0204, https://doi.org/10.33263/Materials22.191204.

9. Norouzi, N.; Talebi, S.; Fani, M. Thermal Energy Storage for the Complex Energy Systems. Mat Int 2020, 2, 0175-0190, https://doi.org/10.33263/Materials22.175190.

10. Seyed Mahmoudi, S.M.; Sarabchi, N.; Yari, M.; Rosen, M.A. Exergy and Exergoeconomic Analyses of a Combined Power Producing System including a Proton Exchange Membrane Fuel Cell and an Organic Rankine Cycle. Sustainability 2019, 11, https://doi.org/10.3390/su11123264.

11. Arshad, A.; Ali, H.M.; Habib, A.; Bashir, M.A.; Jabbal, M.; Yan, Y. Energy and exergy analysis of fuel cells: A review. Thermal Science and Engineering Progress 2019, 9, 308-321, https://doi.org/10.1016/j.tsep.2018.12.008.

12. Wiranarongkorn, K.; Banerjee, A.; Deutschmann, O.; Arpornwichanop, A. Performance analysis and temperature gradient of solid oxide fuel cell stacks operated with bio-oil sorption-enhanced steam reforming. Int. J. Hydrogen Energy 2020, 45, 12108-12120, https://doi.org/10.1016/j.ijhydene.2020.02.120.

13. Ahmed, K.; Amiri, A.; O. Tadé, M. Simulation of Solid Oxide Fuel Cell Anode in Aspen HYSYS-A Study on the Effect of Reforming Activity on Distributed Performance Profiles, Carbon Formation, and Anode Oxidation Risk. Processes 2020, 8 , https://doi.org/10.3390/pr8030268. 
14. Tang, S.; Amiri, A.; Tadé, M.O. System Level Exergy Assessment of Strategies Deployed for Solid Oxide Fuel Cell Stack Temperature Regulation and Thermal Gradient Reduction. Ind. Eng. Chem. Res. 2019, 58, 2258-2267, https://doi.org/10.1021/acs.iecr.8b04142.

15. Behzadi, A.; Habibollahzade, A.; Zare, V.; Ashjaee, M. Multi-objective optimization of a hybrid biomassbased SOFC/GT/double effect absorption chiller/RO desalination system with CO2 recycle. Energy Convers. Manage. 2019, 181, 302-318, https://doi.org/10.1016/j.enconman.2018.11.053.

16. Shayan, E.; Zare, V.; Mirzaee, I. On the use of different gasification agents in a biomass fueled SOFC by integrated gasifier: A comparative exergo-economic evaluation and optimization. Energy 2019, 171, 11261138, https://doi.org/10.1016/j.energy.2019.01.095.

17. Shayan, E.; Zare, V.; Mirzaee, I. Exergoeconomic Analysis of an Integrated Steam Biomass Gasification System with a Solid Oxide Fuel Cell for Power and Freshwater Generations. mdrsjrns 2020, 20, 553-564.

18. Yuksel, B.; Balli, O.; Gunerhan, H.; Hepbasli, A. Comparative Performance Metric Assessment of A Military Turbojet Engine Utilizing Hydrogen And Kerosene Fuels Through Advanced Exergy Analysis Method. Energies 2020, 13, https://doi.org/10.3390/en13051205.

19. Ghorbani, S.; Khoshgoftar Manesh, M.H. Conventional and Advanced Exergetic and Exergoeconomic Analysis of an IRSOFC-GT-ORC Hybrid System. Gas Processing Journal 2020, 8, 1-16, https://doi.org/10.22108/gpj.2019.119599.1067.

20. Sayin Kul, B.; Kahraman, A. Energy and Exergy Analyses of a Diesel Engine Fuelled with Biodiesel-Diesel Blends Containing 5\% Bioethanol. Entropy 2016, 18.

21. Norouzi, N. 4E Analysis and Design of a Combined Cycle with a Geothermal Condensing System in Iranian Moghan Diesel Power Plant. International Journal of Air-Conditioning and Refrigeration 2020, 28, 2050022, https://doi.org/10.1142/S2010132520500224.

22. Fani, M.; Norouzi, N.; Ramezani, M. Energy, Exergy, and Exergoeconomic Analysis of Solar Thermal Power Plant Hybrid with Designed PCM Storage. International Journal of Air-Conditioning and Refrigeration 2020, 28, 2050030, https://doi.org/10.1142/S2010132520500303.

23. Norouzi, N.; Talebi, S.; Najafi, P. Thermal-hydraulic efficiency of a modular reactor power plant by using the second law of thermodynamic. Ann. Nucl. Energy 2021, 151, 107936, https://doi.org/10.1016/j.anucene.2020.107936.

24. Norouzi, N. The Pahlev Reliability Index: A measurement for the resilience of power generation technologies versus climate change. Nuclear Engineering and Technology 2020, https://doi.org/10.1016/j.net.2020.10.013.

25. Norouzi, N.; Fani, M.; Talebi, S. Exergetic design and analysis of a nuclear SMR reactor tetrageneration (combined water, heat, power, and chemicals) with designed PCM energy storage and a CO2 gas turbine inner cycle. Nuclear Engineering and Technology 2021, 53, 677-687, https://doi.org/10.1016/j.net.2020.07.007.

26. Norouzi, N.; Hosseinpour, M.; Talebi, S.; Fani, M. A 4E analysis of renewable formic acid synthesis from the electrochemical reduction of carbon dioxide and water: studying impacts of the anolyte material on the performance of the process. Journal of Cleaner Production 2021, 293, 126149, https://doi.org/10.1016/j.jclepro.2021.126149.

27. Khajehpour, H.; Norouzi, N.; Shiva, N.; Folourdi, R.M.; Bahremani, E.H. Exergy Analysis and Optimization of Natural Gas Liquids Recovery Unit. International Journal of Air-Conditioning and Refrigeration 2020, 10.1142/S201013252150005X, 2150005, https://doi.org/10.1142/s201013252150005x. 